\title{
FREE VIBRATION ANALYSIS OF SPATIAL FRAMES WITH VARIOUS BOUNDARY CONDITIONS
}

\author{
Ljiljana Žugić \\ University of Montenegro, Faculty of Civil Engineering, Podgorica, Montenegro \\ Stanko Brčić \\ University of Montenegro, Faculty of Civil Engineering, Podgorica, Montenegro \\ Špiro Gopčević \\ University of Montenegro, Faculty of Civil Engineering, Podgorica, Montenegro
}

Free vibration analysis of the spatial frames consisting of $3 D$ beam elements is presented in the paper, using the consistent mass matrix, as implemented in the code ALIN, which is written in C++. The values of circular frequencies for the spatial simply supported and clamped-clamped beam, obtained by using ALIN, are compared with the exact solutions and the solutions obtained by using the code TOWER. In order to obtain better, more exact, results, it is necessary to discretize the frame into more finite elements. As opposed to TOWER, which is using the lumped mass matrix, the code ALIN is using the consistent mass matrix, thus allowing wider discretization, into smaller number of finite elements, then in the case of TOWER.

Key words: Prefabricated composite beams, Shear connection, Group of headed studs

\section{INTRODUCTION}

Spatial frames in reality are systems with continuously distributed mass, i.e. systems with infinite number of degrees of freedom. In order to simplify calculation of such systems, continuous mass is substituted by consistent or concentrated mass. Formulation of the consistent mass matrix, applied in this paper and implemented in the originally developed code ALIN, is using the same interpolation functions used in the formulation of the stiffness matrix. Consequently, the consistent mass matrix of beam elements is of the same structure as the stiffness matrix. The concentrated mass matrix of elements has a diagonal structure, which is exacty the reason of its frequent implementation in the commercial computer codes, such as TOWER.

\section{ANALYSIS OF BEAM ELEMENT IN SPACE}

The spatial frames in this paper are represented by 3D beam finite elements with two nodal points and with six dofs at each node. Generalized displacements and the corresponding generalized forces in nodes $i$ and $j$ are the components of the vector of generalized displacements $q$ and the vector of generalized forces $R$

$$
\begin{aligned}
& \mathbf{q}^{\top}=\left[u_{\mathrm{i}} v_{\mathrm{i}} w_{\mathrm{i}} \varphi_{\mathrm{xi}} \varphi_{\mathrm{yi}} \varphi_{\mathrm{zi}} u_{\mathrm{j}} v_{\mathrm{j}} w_{\mathrm{j}} \varphi_{\mathrm{xj}} \varphi_{\mathrm{yj}} \varphi_{\mathrm{zj}}\right] \\
& \mathbf{R}^{\mathrm{T}}=\left[N_{\mathrm{i}} T_{\mathrm{yi}} T_{\mathrm{zi}} M_{\mathrm{xi}} M_{\mathrm{yi}} M_{\mathrm{zi}} N_{\mathrm{j}} T_{\mathrm{yj}} T_{\mathrm{zj}} M_{\mathrm{xj}} M_{\mathrm{yj}} M_{\mathrm{zj}}\right]
\end{aligned}
$$

The stiffness matrix of the 3D beam element $k$ (3) may be obtained by the principle of superposition, i.e. by separation of the spatial state of stress of the element into: axial state, bending in the plane $x y$, bending in the plane $x z$ and the torsion, [03]:

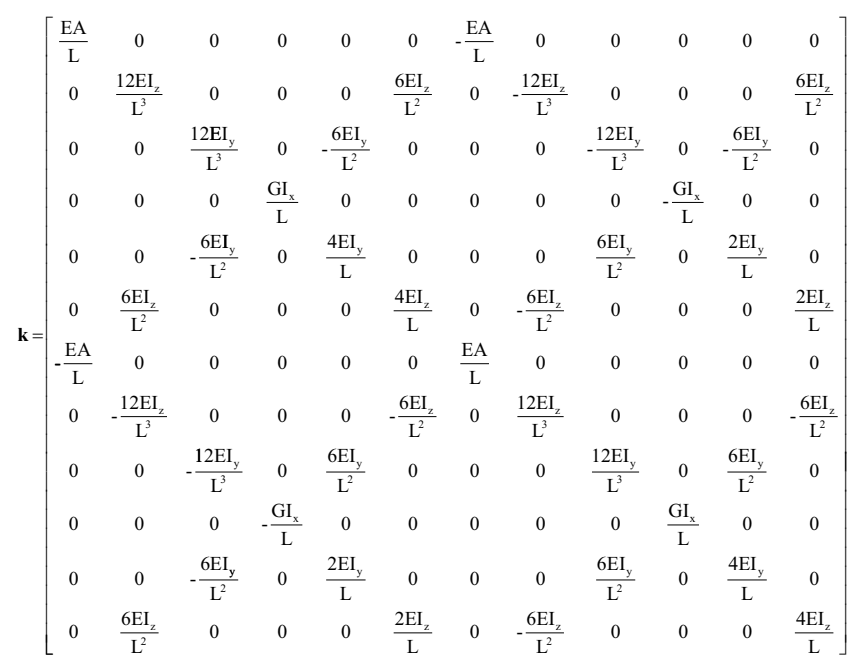




\section{Mass matrix of the beam element}

As it is well known, connection between the vector of the generalized inertial forces Fin and the vector of generalized accelerations $\ddot{\mathbf{q}}$ is established by the mass matrix $\mathbf{m}$ of the element:

$\mathbf{F}_{i n}=-m \ddot{\mathbf{q}}$

Mass matrix $\mathbf{m}$ is determined by the expression:

$\mathbf{m}=\int_{\mathrm{V}} \mathbf{N}^{\mathrm{T}}$ ÁNdV

where $\rho$ is the mass density of the material, and $\mathrm{N}$ is the matrix of interpolation functions.

Mass matrix defined by (5) is called the consistent mass matrix if the same interpolation functions are used as for the displacement field within the element. This mass matrix may be obtained in the same way as the stiffness matrix (3), using the principle of superosition, i.e. by separation of the spatial state of stress into axial state, bending in the plane $x y$ (about $z$ axis), bending in the $x z$ plane (about axis $y$ ) and the torsion.

Consequently, expression (4) may be presented as:

$$
\left[\begin{array}{c}
\mathbf{F}_{\mathrm{a}} \\
\mathbf{F}_{\mathrm{sz}} \\
\mathbf{F}_{\mathrm{sy}} \\
\mathbf{F}_{\mathrm{t}}
\end{array}\right]=-\left[\begin{array}{cccc}
\mathbf{m}_{\mathrm{a}} & & & \\
& \mathbf{m}_{\mathrm{sz}} & & \\
& & \mathbf{m}_{\mathrm{sy}} & \\
& & & \mathbf{m}_{\mathrm{t}}
\end{array}\right]\left[\begin{array}{c}
\ddot{\mathbf{q}}_{\mathrm{a}} \\
\ddot{\mathbf{q}}_{\mathrm{sz}} \\
\ddot{\mathbf{q}}_{\mathrm{sy}} \\
\ddot{\mathbf{q}}_{\mathrm{t}}
\end{array}\right]
$$

where $\mathbf{m}_{\mathrm{a}}$ is the mass matrix of axial vibrations, $\mathbf{m}_{\mathbf{s z}}$ and $\mathbf{m}_{\mathrm{sy}}$ are mass matrices of transverse vibrations in planes $x y$ and $x z$, and $m_{t}$ is the mass matrix of torsional vibrations of the element.

If for the beam element under axial loading one assumes the interpolation functions as follows:

$\mathrm{N}=[1-\xi \xi], \xi=\frac{x}{\mathrm{~L}}$

the consistent mass matrix is obtained as:

$$
\mathbf{m}_{\mathrm{a}}=\frac{\mathrm{A} A \mathrm{~L}}{6}\left[\begin{array}{ll}
2 & 1 \\
1 & 2
\end{array}\right]
$$

If the beam element is exposed to bending in the plane $x y$, i.e. $x z$ and if the corresponding interpolation functions are L'Hermite's polynomials of the first kind:

$\mathbf{N}=\left[1-3 \xi^{2}+2 \xi^{3} L\left(\xi-2 \xi^{2}+\xi^{3}\right) 3 \xi^{2}-2 \xi^{3} L\left(-\xi^{2}+\xi^{3}\right)\right], \xi=\frac{x}{L}$

$\mathbf{N}=\left[1-3 \xi^{2}+2 \xi^{3} L\left(-\xi+2 \xi^{2}-\xi^{3}\right) 3 \xi^{2}-2 \xi^{3} L\left(\xi^{2}-\xi^{3}\right)\right], \xi=\frac{x}{L}$ the consistent mass matrices are:

$\mathbf{m}_{\mathrm{sz}}=\frac{\mathrm{A} A \mathrm{~L}}{420}\left[\begin{array}{cccc}156 & 22 \mathrm{~L} & 54 & -13 \mathrm{~L} \\ 22 \mathrm{~L} & 4 \mathrm{~L}^{2} & 13 \mathrm{~L} & -3 \mathrm{~L}^{2} \\ 54 & 13 \mathrm{~L} & 156 & -22 \mathrm{~L} \\ -13 \mathrm{~L} & -3 \mathrm{~L}^{2} & -22 \mathrm{~L} & 4 \mathrm{~L}^{2}\end{array}\right]$

$\mathbf{m}_{\text {sy }}=\frac{A ́ A L}{420}\left[\begin{array}{cccc}156 & -22 \mathrm{~L} & 54 & 13 \mathrm{~L} \\ -22 \mathrm{~L} & 4 \mathrm{~L}^{2} & -13 \mathrm{~L} & -3 \mathrm{~L}^{2} \\ 54 & -13 \mathrm{~L} & 156 & 22 \mathrm{~L} \\ 13 \mathrm{~L} & -3 \mathrm{~L}^{2} & 22 \mathrm{~L} & 4 \mathrm{~L}^{2}\end{array}\right]$

If one assumes linear distribution of the angle of twist of the beam element exposed to Saint Venant's free torsion, i.e. if linear interpolation functions are assumed:

$\mathrm{N}=[1-\xi \xi], \xi=\frac{x}{\mathrm{~L}}$

the consistent mass matrix is obtained as:

$\mathbf{m}_{\mathrm{t}}=\frac{\dot{\mathrm{A}}_{0} \mathrm{~L}}{6}\left[\begin{array}{ll}2 & 1 \\ 1 & 2\end{array}\right]$

where $I_{0}$ is the polar moment of inertia of the cross section of the beam element.

The consistent mass matrix of 3D beam element (15) is obtained from mass matrices ma, msz, msy and $\mathrm{mt}$, which are given by expressions (8), (11), (12) and (14). Its elements are positioned at the corresponding locations according to the order of generalized accelerations and generalized inertial forces, corresponding to the order of the generalized displacements and forces (first for the node $i$ and then node $\mathrm{j}$ ), as given by expressions (1) and (2).

$\mathbf{m}=\frac{\mathrm{A} A \mathrm{~L}}{420}\left[\begin{array}{cccccccccccc}140 & 0 & 0 & 0 & 0 & 0 & 70 & 0 & 0 & 0 & 0 & 0 \\ 0 & 156 & 0 & 0 & 0 & 22 \mathrm{~L} & 0 & 54 & 0 & 0 & 0 & -13 \mathrm{~L} \\ 0 & 0 & 156 & 0 & -22 \mathrm{~L} & 0 & 0 & 0 & 54 & 0 & 13 \mathrm{~L} & 0 \\ 0 & 0 & 0 & \frac{140 \mathrm{I}_{0}}{\mathrm{~A}} & 0 & 0 & 0 & 0 & 0 & \frac{70 \mathrm{I}_{0}}{\mathrm{~A}} & 0 & 0 \\ 0 & 0 & -22 \mathrm{~L} & 0 & 4 \mathrm{~L}^{2} & 0 & 0 & 0 & -13 \mathrm{~L} & 0 & -3 \mathrm{~L}^{2} & 0 \\ 0 & 22 \mathrm{~L} & 0 & 0 & 0 & 4 \mathrm{~L}^{2} & 0 & 13 \mathrm{~L} & 0 & 0 & 0 & -3 \mathrm{~L}^{2} \\ 70 & 0 & 0 & 0 & 0 & 0 & 140 & 0 & 0 & 0 & 0 & 0 \\ 0 & 54 & 0 & 0 & 0 & 13 \mathrm{~L} & 0 & 156 & 0 & 0 & 0 & -22 \mathrm{~L} \\ 0 & 0 & 54 & 0 & -13 \mathrm{~L} & 0 & 0 & 0 & 156 & 0 & 22 \mathrm{~L} & 0 \\ 0 & 0 & 0 & \frac{70 \mathrm{I}_{0}}{\mathrm{~A}} & 0 & 0 & 0 & 0 & 0 & \frac{140 \mathrm{I}_{0}}{4} & 0 & 0 \\ 0 & 0 & 13 \mathrm{~L} & 0 & -3 \mathrm{~L}^{2} & 0 & 0 & 0 & 22 \mathrm{~L} & 0 & 4 \mathrm{~L}^{2} & 0 \\ 0 & -13 \mathrm{~L} & 0 & 0 & 0 & -3 \mathrm{~L}^{2} & 0 & -22 \mathrm{~L} & 0 & 0 & 0 & 4 \mathrm{~L}^{2}\end{array}\right]$

In order to simplify analysis and calculation, the total inertial force of the finite element is uniformly distributed as concentrated forces at nodes, 
by using the concentrated mass matrix. It has a diagonal structure due to assumption that accelerations of the element in direction of some generalized displacement are generating inertial forces only in that direction.

In this case, for the 3D beam element, the concentrated mass matrix is given as:

$\mathbf{m}=\frac{\mathrm{A} A \mathrm{~L}}{2} \mathbf{I}$

where $\mathbf{I}$ is the unit matrix of the twelfth order.

In order to further simplify, one may assume that certain diagonal elements of the concentrated mass matrix (16) are equal to zero, i.e. one may assume that not all degrees of freedom are of the same importance in dynamic analysis (e.g. by neglecting the influence of the so-called „rotational inertia" terms).

\section{ANALYSIS OF FREE VIBRATIONS OF THE SYSTEM}

Differential equations of motion of the free undamped vibrations of the system, in the matrix form, are given as:

$$
\mathbf{M} \ddot{\mathbf{q}}+\mathbf{K q}=\mathbf{0}
$$

where $\mathbf{M}$ and $\mathbf{K}$ are mass and stiffness matrices, while $\mathrm{q}$ and are the vectors of the generalized displacements and accelerations of the nodes of the system.

In solution of Eqs. (17) one assumes that all generalized displacements of nodes $q_{i}(t)(i=1,2, \ldots, n)$ are changing synchronously and synphasely. Therefore, the solution of Eqs. (17) is assumed as:

$\mathbf{q}(\mathrm{t})=\overline{\mathbf{q}} \cos (\mathrm{E} t-\phi)$

where $\overline{\mathbf{q}}$ - constant vector of order $n, \omega$ - circular frequency of free vibrations and $\varphi$ - phase angle of free vibrations.

If assumed solution (18) is inserted into Eqs. (17), one obtains:

$$
\left(\mathbf{K}-\dot{E}^{2} \mathbf{M}\right) \overline{\mathbf{q}}=0
$$

Relation (19) represents, in the mathematical sense, the eigenvalue problem of the pair of matrices $\mathbf{K}$ and $\mathbf{M}$. It is necessary to determine the values $\omega^{2}$ for which there is a non-trivial solution for constants $\overline{\mathbf{q}}$. The system of homogeneous algebraic equations (19) has a non-trivial solution if the determinant of the system is equal to zero, i.e.:

$$
\operatorname{det}\left[\mathbf{K}-\dot{E}^{2} \mathbf{M}\right]=0
$$

If expression (20) is developed, it represents the characteristic polynomial equation of order $n$ in $\omega^{2}$. Since matrices $\mathbf{K}$ and $\mathbf{M}$ are symmetric and positive definite, all roots of the characteristic polynomial equation are real, positive ane mutually different: $\omega_{1}{ }^{2}, \omega_{2}{ }^{2}, \ldots, \omega_{n}{ }^{2}$. They represent the eigenvalues of the system, while the square roots of these values: $\omega_{1}, \omega_{2}, \ldots, \omega_{n}$ are the natural circular frequencies of the system, where:

$\left(\mathbf{K}-\mathrm{E}_{\mathrm{r}}^{2} \mathbf{M}\right) \overline{\mathbf{q}}^{\mathrm{r}}=0 \quad(r=1,2, \ldots, n)$

Since equations (21) are homogeneous, elements of the eigenvector $\overline{\mathbf{q}}^{\mathrm{r}}$ are determined up to the constant factor.

The eigenvalue problem of the pair of matrices $\mathbf{K}$ and $\mathbf{M}$ (19), represents the generalized eigenvalue problem, which, by the corresponding transformations [02], may be reduced to the standard eigenvalue problem:

$\mathbf{A x}=» \mathbf{x}$

Advantages of transformation of the generalized eigenvalue problem into the standard problem is in the fact that there are more very efficient algorithms for the solution of the standard eigenvalue problem (e.g. Jacobi and Lanczos algorithm).

\section{NUMERICAL EXAMPLE}

Incorporating previously discussed solutions, the computer code ALIN was developed [05], using programming language $\mathrm{C}++$. The code is oriented to dynamic analysis of spatial frames, in this case to free vibration analysis of spatial frames.

Using the code ALIN, this paper is presenting the free undamped vibration analysis of two spatial girders (Figures 1-2), which are different only in boundary conditions: one is the spatial simply supported beam, and the other is a clampedclamped beam. Obtained values of circular frequencies are compared with results obtained using the code TOWER and also with exact solutions obtained for the continuous systems with infinite number of dofs, given in literature [02].

Tabeles 1-4 are presening the values of circular frequenciies of free undamped vibrations for the first three modes in plane $x y$, i.e. $x z$, of considered beams, obtained by ALIN and TOWER, using different discretizations into finite elements. The cases when beams are treated as a single finite element and then discretizad into 2, 3, 4 and 5 finite elements are considered. Obrained values of circular frequencies are compared with exact values obtained from [02]. 


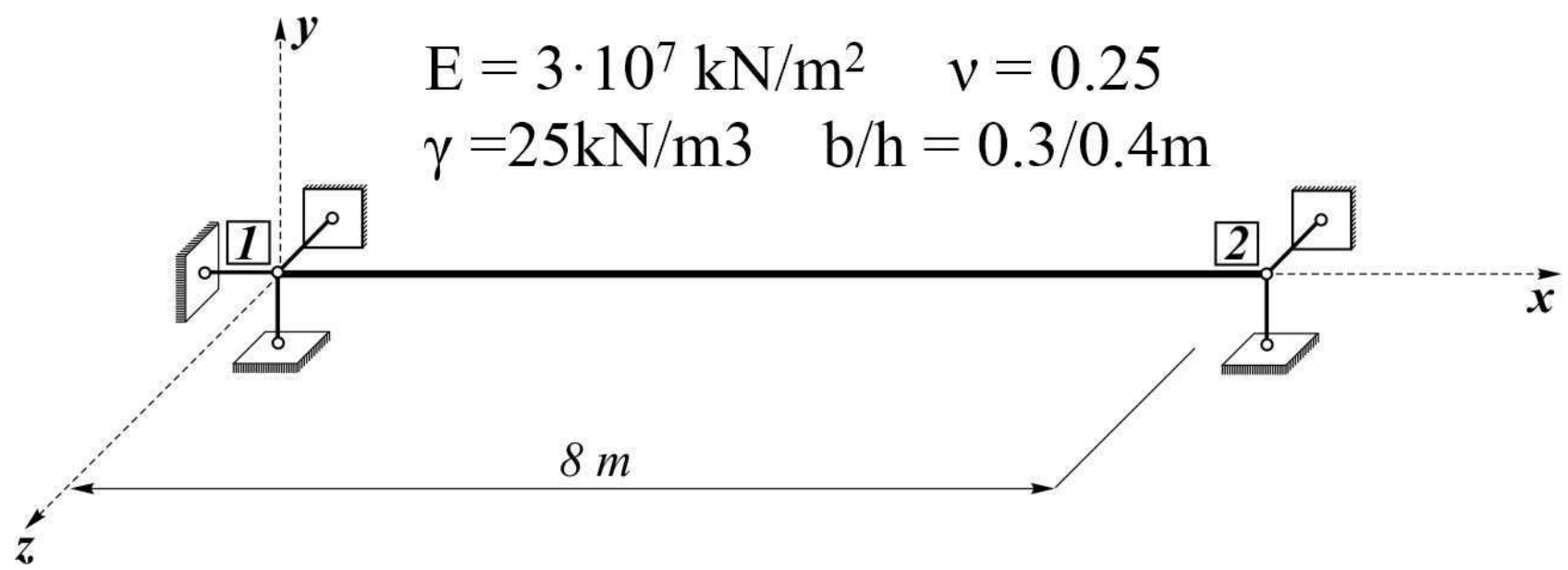

Figure 1: Spatial simply supported beam

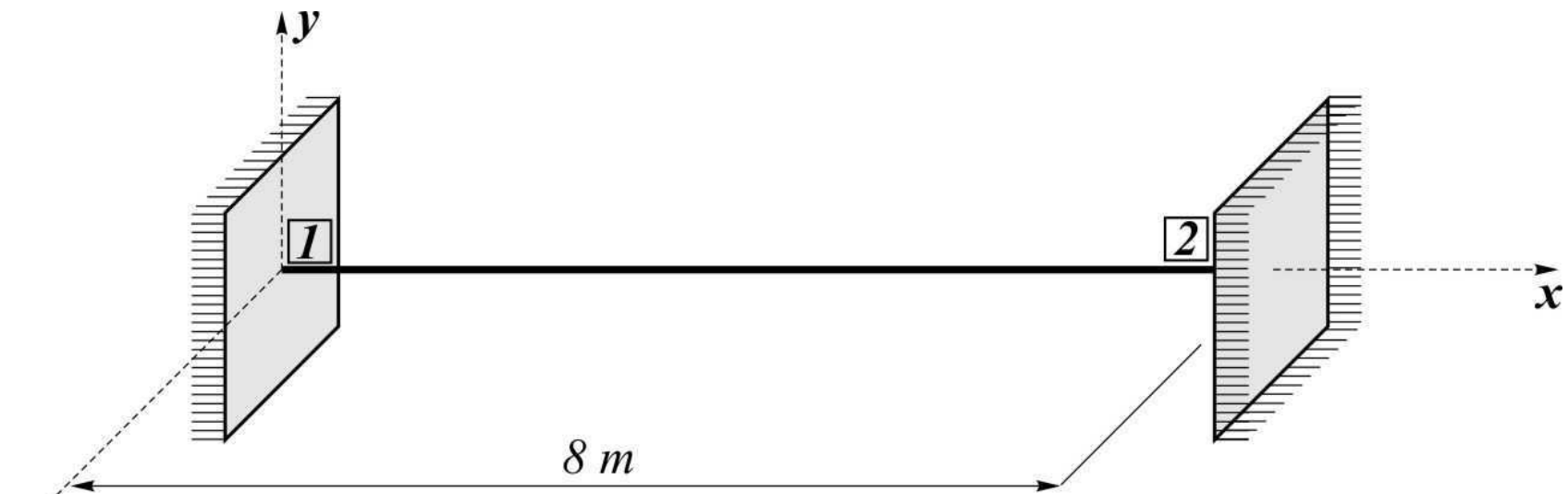

Figure 2: Spatial clamped-clamped beam

Tabeles 1-4 are presening the values of circular frequenciies of free undamped vibrations for the first three modes in plane $x y$, i.e. $x z$, of considered beams, obtained by ALIN and TOWER, using different discretizations into finite elements. The cases when beams are treated as a single

Table 1: Circular frequencies of free vibrations in xy plane of a spatial simply supported beam

\begin{tabular}{|c|c|c|c|c|c|c|c|c|c|c|c|c|c|c|c|}
\hline \multirow{4}{*}{$\frac{1}{8}$} & \multicolumn{10}{|c|}{ Circular frequencies [rad/s] } & \multirow{3}{*}{\multicolumn{5}{|c|}{ Difference [\%] }} \\
\hline & \multirow{2}{*}{$\begin{array}{l}\text { Exact } \\
\text { sol. [4] }\end{array}$} & \multicolumn{5}{|c|}{ ALIN } & \multicolumn{4}{|c|}{ TOWER } & & & & & \\
\hline & & 1f.e & 2f.e & 3f.e & $4 f . e$ & $5 f . e$ & 2f.e & 3f.e & $4 f . e$ & $5 f . e$ & & & & & \\
\hline & $/ 1 /$ & 121 & $/ 3 /$ & $14 /$ & /5/ & /6/ & 171 & /8/ & /9/ & $/ 10 /$ & $\mid 2 /-/ 1 /$ & $\begin{array}{l}|3 /-/ 1| \\
|7|-/ 1 \mid\end{array}$ & $\begin{array}{l}\mid 4 /-/ 1 / \\
\mid 8 /-/ 1 /\end{array}$ & $\begin{array}{l}/ 5 /-/ 1 / \\
/ 9 /-/ 1 /\end{array}$ & $\begin{array}{l}\mid 6 /-/ 1 / \\
\mid 10 /-/ 1 /\end{array}$ \\
\hline 1 & 61.10 & 67.81 & 61.34 & 61.15 & 61.11 & 61.10 & 60.43 & 60.82 & 60.88 & 60.89 & 10.99 & $\begin{array}{l}0.39 \\
-1.10\end{array}$ & $\begin{array}{c}0.08 \\
-0.45\end{array}$ & \begin{tabular}{|c|}
0.03 \\
-0.36
\end{tabular} & $\begin{array}{c}0.01 \\
-0.33\end{array}$ \\
\hline 2 & 244.39 & 310.75 & 271.25 & 245.35 & 245.33 & 244.79 & - & 232.59 & 239.15 & 240.52 & 27.16 & $\begin{array}{c}10.99 \\
-\end{array}$ & $\begin{array}{c}1.18 \\
-4.83\end{array}$ & $\begin{array}{c}0.39 \\
-2.14\end{array}$ & $\begin{array}{c}0.17 \\
-1.58\end{array}$ \\
\hline 3 & 549.87 & - & 681.80 & 610.31 & 55.91 & 554.23 & - & - & 496.50 & 521.69 & - & $\begin{array}{c}23.99 \\
-\end{array}$ & $\begin{array}{c}10.99 \\
-\end{array}$ & $\begin{array}{l}1.83 \\
-9.71\end{array}$ & $\begin{array}{c}0.79 \\
-5.12\end{array}$ \\
\hline
\end{tabular}

finite element and then discretizad into 2, 3, 4 and 5 finite elements are considered. Obrained values of circular frequencies are compared with exact values obtained from [02]. 
Table 2: Circular frequencies of free vibrations in xz plane of a spatial simply supported beam

\begin{tabular}{|c|c|c|c|c|c|c|c|c|c|c|c|c|c|c|c|}
\hline \multirow[b]{4}{*}{$\stackrel{0}{2}$} & \multicolumn{10}{|c|}{ Circular frequencies [rad/s] } & \multirow{3}{*}{\multicolumn{5}{|c|}{ Difference [\%] }} \\
\hline & \multirow{3}{*}{$\begin{array}{c}\begin{array}{c}\text { Exact } \\
\text { sol. [4] }\end{array} \\
/ 1 /\end{array}$} & \multicolumn{5}{|c|}{ ALIN } & \multicolumn{4}{|c|}{ TOWER } & & & & & \\
\hline & & $1 f . e$ & $2 f . e$ & $3 f . e$ & $4 f . e$ & $5 f . e$ & $2 f . e$ & $3 f . e$ & $4 f . e$ & $5 f . e$ & & & & & \\
\hline & & 121 & /3/ & $14 /$ & |5/ & /6/ & 171 & /8/ & /9/ & $/ 10 /$ & $\mid 2 / / / 1 /$ & $\begin{array}{l}\mid 3 /-/ 1 / \\
\mid 7 /-/ 1 /\end{array}$ & $\begin{array}{l}|4 /-/ 1| \\
|8 /-/ 1|\end{array}$ & \begin{tabular}{|l|}
$/ 5 /-/ 1 /$ \\
$\mid 9 /-/ 1 /$
\end{tabular} & $\begin{array}{l}\mid 6 /-/ 1 / \\
\mid 10 /-/ 1 /\end{array}$ \\
\hline 1 & 45.82 & 50.86 & 46.00 & 45.86 & 45.83 & 45.83 & 45.39 & 45.68 & 45.72 & 45.73 & 10.99 & $\begin{array}{r}0.39 \\
-0.94\end{array}$ & $\begin{array}{l}0.08 \\
-0.31\end{array}$ & $\begin{array}{r}0.03 \\
-0.22\end{array}$ & $\begin{array}{c}0.01 \\
-0.20\end{array}$ \\
\hline 2 & 183.29 & 233.06 & 203.44 & 185.45 & 184.01 & 183.59 & - & 175.66 & 180.47 & 181.43 & 27.16 & $\begin{array}{c}10.99 \\
-\end{array}$ & $\begin{array}{c}1.18 \\
-4.17\end{array}$ & \begin{tabular}{|c|}
0.39 \\
-1.54
\end{tabular} & $\begin{array}{c}0.17 \\
-1.01\end{array}$ \\
\hline 3 & 412.40 & - & 511.35 & 457.73 & 415.68 & 415.68 & - & - & 378.25 & 396.97 & - & $\begin{array}{c}23.99 \\
-\end{array}$ & $\begin{array}{c}10.99 \\
-\end{array}$ & \begin{tabular}{|r|}
1.83 \\
-8.28
\end{tabular} & $\begin{array}{c}0.79 \\
-3.74\end{array}$ \\
\hline
\end{tabular}

Table 3: Circular frequencies of free vibrations in xy plane of a spatial clamped-clamped beam

\begin{tabular}{|c|c|c|c|c|c|c|c|c|c|c|c|c|c|c|c|}
\hline \multirow{4}{*}{$\begin{array}{l}\frac{0}{0} \\
\frac{0}{2}\end{array}$} & \multicolumn{10}{|c|}{ Circular frequencies [rad/s] } & \multirow{3}{*}{\multicolumn{5}{|c|}{ Difference [\%] }} \\
\hline & \multirow{3}{*}{$\begin{array}{c}\begin{array}{c}\text { Exact } \\
\text { sol. [4] }\end{array} \\
/ 1 /\end{array}$} & \multicolumn{5}{|c|}{ ALIN } & \multicolumn{4}{|c|}{ TOWER } & & & & & \\
\hline & & $1 f . e$ & $2 f . e$ & $3 f . e$ & $4 f . e$ & $5 f . e$ & $2 f . e$ & 3f.e & $4 f . e$ & $5 f . e$ & & & & & \\
\hline & & $/ 2 /$ & $/ 3 /$ & /4/ & /5/ & /6/ & 17/ & 18/ & 19/ & /10/ & $\mid 2 /-/ 1 /$ & $\begin{array}{l}\mid 3 /-/ 1 / \\
\mid 7 /-/ 1 /\end{array}$ & $\begin{array}{l}|4 /-/ 1| \\
\mid 8 /-/ 1 /\end{array}$ & $\begin{array}{l}\mid 5 /-/ 1 / \\
\mid 9 /-/ 1 /\end{array}$ & $\begin{array}{l}\mid 6 /-/ 1 / \\
\mid 10 /-/ 1 /\end{array}$ \\
\hline 1 & 138.50 & - & 140.74 & 139.07 & 138.68 & 138.57 & 119.58 & 134.29 & 135.92 & 136.25 & - & $\begin{array}{c}1.62 \\
-13.66\end{array}$ & $\begin{array}{c}0.41 \\
-3.04\end{array}$ & $\begin{array}{r}0.13 \\
-1.86\end{array}$ & $\begin{array}{l}0.05 \\
-1.62\end{array}$ \\
\hline 2 & 381.78 & - & - & 398.40 & 385.31 & 383.30 & - & 307.38 & 353.70 & 364.14 & - & - & $\begin{array}{r}2.00 \\
-7.35\end{array}$ & $\begin{array}{l}0.92 \\
-7.35\end{array}$ & $\begin{array}{l}0.40 \\
-4.62\end{array}$ \\
\hline 3 & 748.43 & - & - & - & 764.42 & 758.79 & - & - & 571.56 & 657.93 & - & - & - & $\begin{array}{c}2.14 \\
-23.63\end{array}$ & $\begin{array}{c}1.38 \\
-12.09\end{array}$ \\
\hline
\end{tabular}

Table 4: Circular frequencies of free vibrations in xz plane of a spatial clamped-clamped beam

\begin{tabular}{|c|c|c|c|c|c|c|c|c|c|c|c|c|c|c|c|}
\hline \multirow{4}{*}{$\begin{array}{l}\frac{1}{0} \\
\frac{0}{2}\end{array}$} & \multicolumn{10}{|c|}{ Circular frequencies [rad/s] } & \multirow{3}{*}{\multicolumn{5}{|c|}{ Difference [\%] }} \\
\hline & \multirow{3}{*}{$\begin{array}{c}\begin{array}{c}\text { Exact } \\
\text { sol. [4] }\end{array} \\
/ 1 /\end{array}$} & \multicolumn{5}{|c|}{ ALIN } & \multicolumn{4}{|c|}{ TOWER } & & & & & \\
\hline & & $1 \mathrm{f} . \mathrm{e}$ & $2 f . e$ & 3f.e & $4 f . e$ & $5 f . e$ & $2 f . e$ & 3f.e & $4 f . e$ & $5 f . e$ & & & & & \\
\hline & & /2/ & $/ 3 /$ & 141 & $15 /$ & /6/ & 171 & /8/ & /9/ & $/ 10 /$ & $/ 2 /-/ 1 /$ & $\begin{array}{l}|3 /-/ 1| \\
|7 /-/ 1|\end{array}$ & $\begin{array}{l}\mid 4 /-/ 1 / \\
\mid 8 /-/ 1 /\end{array}$ & $\begin{array}{l}\mid 5 /-/ 1 / \\
\mid 9 /-/ 1 /\end{array}$ & $\begin{array}{l}\mid 6 /-/ 1 / \\
\mid 10 /-/ 1 /\end{array}$ \\
\hline 1 & 103.87 & - & 105.56 & 104.30 & 104.01 & 103.93 & 90.24 & 101.41 & 102.62 & 102.86 & - & $\begin{array}{c}1.62 \\
-13.13\end{array}$ & $\begin{array}{c}0.41 \\
-2.37\end{array}$ & $\begin{array}{l}0.13 \\
-1.20\end{array}$ & $\begin{array}{l}0.05 \\
-0.98\end{array}$ \\
\hline 2 & 286.33 & - & - & 292.05 & 288.98 & 287.48 & - & 233.63 & 269.63 & 277.27 & - & - & $\begin{array}{c}2.00 \\
-18.41 \\
\end{array}$ & $\begin{array}{l}0.92 \\
-5.91 \\
\end{array}$ & $\begin{array}{l}0.40 \\
-3.17 \\
\end{array}$ \\
\hline 3 & 561.33 & - & - & - & 573.31 & 569.09 & - & - & 438.46 & 506.55 & - & - & - & $\begin{array}{c}2.14 \\
-21.89\end{array}$ & $\begin{array}{r}1.38 \\
-9.76\end{array}$ \\
\hline
\end{tabular}

When using ALIN, if the beam is not divided into smaller segments, i.e. if the beam is a single finite element, the first and the second vibration mode in planes $x y$ and $x z$ exists for simply supported spatial beam (tables 1-2) since its nonhomogeneous boundary conditions allow such deformation, i.e. vibration mode. When using the commercial code TOWER in this case there is no vibration mode, because TOWER uses the concentrated mass matrix, as opposed to ALIN which is using consistent mass matrix. Circular frequency of the first, i.e. the second vibration modes in planes $x y$ and $x z$ of the spatial simply supported beam, using the code ALIN, is different from the exact solution by $10.99 \%$, or $27.16 \%$, if one uses a single finite element.

If discretization of the beams into smaller segments is done, the following results are obtained. Considering the spatial simply supported beam (tables 1-2), circular frequency of the first mode in $x y$ and $x z$ planes obtained by ALIN is different from the exact solution by $0.39 \%$ for two finite 
elements, $0.08 \%$ for three finite elements, and $0.01 \%$ for five finite elements. Using the code TOWER, the difference is $-1.10 \%,-0.45 \%$ and $-0.33 \%$. Circular frequency of the second mode, obtained by ALIN, is different from the exact solution by $10.99 \%$ for two elements, $1.18 \%$ for three elements and $0.17 \%$ for five elements, while using TOWER the error is $-4.17 \%$ for three finite elements and $-1.58 \%$ for five elements. For the third mode the circular frequency obtained by ALIN is different by $23.99 \%$ for two elements, $10.99 \%$ for three elements and $0.79 \%$ for five finite elements, while when using TOWER the error is $-9.71 \%$ for four finite elements and $-8.12 \%$ for five elements. Therefore, when using TOW$E R$, if one uses two finite elements for a beam there are no second and third vibration modes of the spatial simply supported beam in planes $x y$ and $x z$, while when three elements are used there is no the third vibration mode, since TOWER is using concentrated mass matrix.

When considering the spatial clamped-clamped beam (tables 3-4) circular frequency of the first vibration mode in $x y$ and $x z$ planes, obtained using ALIN, is different from the exact solution by $1.62 \%$ for two finite elements, and $0.05 \%$ if using five elements. If using TOWER, the error is $-13.66 \%$ for two elements and $-1.62 \%$ for five elements. Circular frequency of the second mode, obtained using ALIN, is different from the exact solution by $2 \%$ for three elements and $0.4 \%$ for five elements, while using TOWER the error is $19.49 \%$ and $-4.62 \%$. When considerting the third mode, using ALIN and four elements obtained error is $2.14 \%$, while using five elements, the error is $1.38 \%$. On the other hand, using TOWER and four and five elements, errors are $-23.63 \%$ and $-12.09 \%$.

Analysing obtained results one may notice that circular frequencies of free vibrations of considered beams using two finite elements and code ALIN are approximately correct only for the first mode (error is $0.39 \%$ for simply supported beam and $1.62 \%$ for clamped-clamped beam). Using the code TOWER and discretization of a beam into two finite elements one may notice that the circular frequency of simply supported beam is approximately exact for the first mode (error is $-1.10 \%$ ), while for the clamped-clamped beam obtained result is not correct, since the error is larger then $10 \%(13.66 \%)$.

Therefore, when determining circular frequen- cies especially for higher modes, in order to obtain more correct results, it is necessary to divide beams into as much finite elements as possible. However, since ALIN is using the consistent mass matrix, division into finite elements may be smaller (i.e. less finite elements) then when using TOWER.

\section{REFERENCES}

1) Brčić S.: Dinamika diskretnih sistema, Studentski kulturni centar, Beograd, 1998.

2) Karnovsky I., Lebed O.: Formulas for Structural Dynamics: Tables, Graphs and Solutions, McGraw-Hill, 2004.

3) Sekulović M.: Teorija linijskih nosača, Građevinska knjiga, Beograd, 2005.

4) TOWER 6, Uputstvo za rad sa programom, Radimpex, Beograd

5) Žugić Lj: Nelinearna analiza mostova sa kosim kablovima, doktorska disertacija, Univerzitet u Beogradu, Građevinski fakultet Beograd, 2009.

Paper sent to revision: 04.02.2016.

Paper ready for publication: 15.03.2016. 


\section{ANALIZA SLOBODNIH OSCILACIJA PROSTORNIH LINIJSKIH NOSAČA} RAZLIČITIH KONTURNIH USLOVA

\section{Ljiljana Žugić, Univerzitet Crne Gore, Podgorica, Crna Gora}

Stanko Brčić, Univerzitet u Beogradu, Beograd, Srbija

Špiro Gopčević, Visoka železnička škola strukovnih studija, Beograd, Srbija

$U$ radu je prikazana analiza slobodnih oscilacija prostornih linijskih nosača primjenom konzistentne matrice masa, odnosno programa ALIN koji je napisan u programskom jeziku C++. Vrijednosti kružnih frekvencija za prostornu prostu gredu i prostornu uklještenu gredu, dobijene korišćenjem programa ALIN su upoređene sa tačnim vrijednostima, kao i sa vrijednostima dobijenim korišćenjem programa TOWER. Da bi se dobili što tačniji rezultati, potrebno je podijeliti nosače na veći broj konačnih elemenata. Za razliku od programa TOWER, koji koristi koncentrisanu matricu masa, program ALIN koristi konzistentnu matricu masa, pa podjela nosača može biti krupnija nego pri primjeni programa TOWER.

Ključne reči: Konzistentna matrica masa, Koncentrisana matrica masa, Kružna frekvencija 